\title{
Unconventional Memoirs: Mary Fortune's Account of Life on the Diggings
}

\section{Alice Michel}

\section{(2) OpenEdition}

1 Journals

Electronic version

URL: http://journals.openedition.org/ces/4138

DOI: $10.4000 /$ ces.4138

ISSN: 2534-6695

Publisher

SEPC (Société d'études des pays du Commonwealth)

\section{Electronic reference}

Alice Michel, «Unconventional Memoirs: Mary Fortune's Account of Life on the Diggings »,

Commonwealth Essays and Studies [Online], 43.1 | 2020, Online since 30 October 2020, connection on 10 November 2020. URL : http://journals.openedition.org/ces/4138 ; DOI : https://doi.org/10.4000/ ces. 4138

This text was automatically generated on 10 November 2020 .

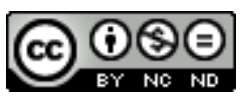

Commonwealth Essays and Studies is licensed under a Licence Creative Commons Attribution - Pas d'Utilisation Commerciale - Pas de Modification 4.0 International. 


\title{
Unconventional Memoirs: Mary Fortune's Account of Life on the Diggings
}

\author{
Alice Michel
}

"Who would write pages at fifteen shillings when one paid nine shillings per day for milk, and for a 'woman's' magazine, too! Nay, there was nothing of the namby-pamby elegance of ladies' literature in our stirring, hardy, and eventful life on the early goldfields." This claim is made by Waif Wander - real name Mary Fortune (1833-1909) in the narrative of her exceptional life on the Australian goldfields (Fortune 1882-83, 33). In "Twenty-Six Years Ago: or, the Diggings from '55," published in The Australian Journal (1882-83), Fortune provides an autobiographical account of an unconventional woman's life on the Australian goldfields, in the first years of the gold rush in the colony of Victoria (1851 to late 1960s). This period is characterised by major changes at different social levels: greater parliamentary democracy following diggers' protests, in the wake of the Eureka Rebellion (1854), extraordinary population growth due to massive immigration to Victoria and booming economic development of Melbourne thanks to the discovery of gold in the surrounding areas. Melbourne was the main access point to the gold mines; therefore, at the beginning of the gold rush, two to three ships a day landed at Melbourne from Europe, whereas it was common to see up to three hundred ships mooring in Port Phillip Bay, south of Melbourne (Davison 2011, 53-54). In just one year, Melbourne went from 23,000 inhabitants (1851) to 80,000 (1852) (Howitt 2010, 283). As gold aroused covetousness, Melbourne, and more generally the colony of Victoria, became the main destination of British emigrants. Between 1851 and 1861, the population was multiplied by four, turning a small pioneer colony into a metropolis. The very name of "Melbourne" was synonymous with luck and wealth in many parts of the world, from London to Guangzhou by way of Hamburg and Boston (Davison 2011, 52). Fortune's text gives us a glimpse at this vibrant period, remembering her first stay in Melbourne: "I carried up to the diggings a few prominent memories of the city at that day, and it is strange to note with what pertinacity first 
and new impressions will cling to the brain upon which they have been photographed" (Fortune 1882-83, 35).

2 But her text also emphasises her rejection of colonial norms, representing nineteenthcentury Australia not merely as a space onto which British cultural, gender and literary conventions could be projected, but as a place where women could assert and narrate their individual experience. Away from the domestic representation of women that could be found in feminine colonial romances (such as Ada Cambridge's), Fortune places her female characters out of the home and into the public life. She narrates the ongoing social changes and the inclusion of women in them, by offering the reader an insider's view into these key moments of the history of colonial Australia. She does so in the form of journalism as well as short stories and serial novels. Generally speaking, Fortune's journalism is a precious source of information about Victoria's colonial society. Nevertheless, what makes her writings particularly interesting is the fact that they are situated at the crossroads between fiction, autobiography and journalism, as we will see in what follows.

3 Fortune's narrative belongs to the important number of texts written by women in the Australian colonies that have been dismissed in the course of the twentieth century despite their considerable popularity when they were published. Too few of them have been paid scholarly attention, even if since the 1980s, critical works have paved the way for the recognition of Australian colonial women writers. Among them, Dale Spender defines these writers as a "submerged' heritage" which "produced a very different view of the world from that encoded by men" (1988, XIV-XV), while Debra Adelaide invites us "to re-read the history of Australian literature" from the point of view of women writers $(1988,1)$. Susan Sheridan also reconsiders neglected women's fiction and journalism, arguing that women writers of nineteenth-century Australia "were never the silenced outsiders that later historians and critics rendered them" (1995, VIII). According to Debra Adelaide, one ought not to dismiss early colonial authors, despite the focus usually put upon the 1890s as a period "reflect[ing] strongly the development of nationalist thinking" $(1988,7)$. Finally, the reassessment of colonial Australia's serial publication has been undertaken by Elizabeth Morrison (1995), as well as Ken Gelder and Rachael Weaver (2010).

In this light, Australia's fictional archive contains exceptional yet forgotten narratives written by women in nineteenth-century journals, which could be re-evaluated and potentially validated as having a place in Australian literary history. Among them can be found Mary Fortune's narrative of life on the diggings, "Twenty-Six Years Ago," never published in book form. The then-famous author writing under the pen-name "Waif Wander" is now barely remembered, although she was a keen observer of the colonial society in Victoria and of women's place therein. Tackling issues ranging from women's status as journalists and writers to financial and marital independence, her series draws on the genre of autobiographical journalism to assert the marginality of her life and writing.

5 This article seeks to stress the unconventionality of Mary Fortune's memoirs, in order to contribute to their re-evaluation. It considers her exclusion from the Australian literary histories, takes her eccentric and marginal way of life into account, and rereads, in light of this, her exceptional memoirs written beyond the norms of genre and gender. 


\section{Between exception and exclusion}

6 The series of articles entitled "Twenty-Six Years Ago: Or, the Diggings from '55" was published in The Australian Journal in five instalments, from September 1882 to May 1883. The first of them is entitled "Arrival in Melbourne," but the other four have no specific titles. "Twenty-Six Years Ago" is an autobiographical text in which Mary Fortune narrates her arrival in Victoria, when the colony was starting to rapidly grow, as well as her experience on the goldfields during her first two Australian years, "[her] recollection of [her] earliest colonial days" (Fortune 1882-83, 33), chronologically narrated in the form of anecdotes. The notes used by Fortune to write these articles were taken when she arrived in Melbourne in October 1855. Her original aim was to write articles for the London paper Ladies' Companion, but she decided not to go through with this publication. This shows her desire for independence and her refusal to abide by the conventions of what was considered feminine literature, even if she could have made good copy, as narratives about the goldrush were very popular in England. John Elphinstone Erskine's A Short Account of the Late Discoveries of Gold in Australia: With Notes of a Visit to the Gold District (1851), and Ellen Clacy's A Lady's Visit to the Gold Diggings of Australia in 1851-53 are good examples. The adventures that Clacy narrates raise a striking contrast with the usual representation of a young woman of the time, something that Clacy acknowledges in a preliminary note: "It may be deemed presumptuous that one of my age and sex should venture to give to the public an account of personal adventures in a land which has so often been descanted upon by other and abler pens [...]" $(1853,114)$. Fortune, despite her initial refusal, can be inscribed in the line of rare women who narrated their experience on the goldfields, a place generally considered as male. A major difference between Clacy's and Fortune's narratives is that Fortune keeps hiding her identity and never mentions her marital status, either in her narratives, or in her penname, which was quite noteworthy in the Victorian era known for valuing female virtue. ${ }^{1}$

Despite the autobiographical references, Fortune takes care not to completely disclose her identity. The presence of her initials ("M.H.F") in this story was the most important clue ever given to her readers and it would never be followed by others, confirming her intention not to disclose her identity, since her exceptional way of life could have led to criticism on the part of her contemporaries at a time when she needed to write to earn a living on her own. In spite of this anonymity and marginality, she was one of the most popular writers of nineteenth-century Australia and wrote serial novels, poetry and journalism, most of her texts being published in The Australian Journal. She was also very prolific, writing more than five hundred stories. However, even though her texts were popular during her lifetime, Fortune fell into oblivion after her death, so that her professional and personal lives have long remained mysteries, until her identity was rediscovered by the book collector John Kinmont Moir. In the 1950s, he found manuscripts of her poems signed with her initials, as well as a letter dating from 1909, signed "M.H. Fortune," enabling him to establish a link between them. Later, in the 1980s, the journalist and researcher Lucy Sussex cast light on Waif Wander's main biographical information, which point to an eccentric, nonconformist way of life.

Born in 1833 in Belfast as Mary Wilson, Fortune left Ireland with her father to go to Canada when she was a child. She married twice, the first time in Canada to Joseph Fortune, before leaving with their son for Australia in 1855 to join her father on the 
goldfields of Victoria. She crossed the world alone with her young boy, and then continued her lonely journey across Victoria, from Melbourne to the goldfields, in an unknown land. After her arrival in Victoria, she had a second son a year later and claimed that Joseph Fortune was the father. Yet evidence has shown since that Joseph had never been to Australia, raising doubts about the child's legitimacy. In 1858, Mary Fortune remarried, stating she was a widow. Further biographical research was to reveal that Joseph Fortune died in 1861 in Canada, without being divorced from Mary Fortune (Sussex 1988, 121). This bigamous situation and the illegitimacy of her second child are part of the "secrets that could threaten her reputation and her livelihood as a female author" and partly explain why she wrote anonymously (Sussex 2009). However, despite the success of her stories, Fortune lived in poverty and ended up homeless and alcoholic. As she aged, her eyesight also deteriorated, preventing her from maintaining her writing, and consequently forcing her to ask The Australian Journal for an annuity. It is now known that she died in 1909 (Sussex 2009). Yet until 2015, the exact date and place remained unknown (Sussex 2016). With hindsight, her pseudonym "Waif Wander" can therefore be interpreted as hinting at several aspects of both her life and work: her geographical mobility, her non-conformism, and her writing experience. If mysteries surrounding this exceptional writer are starting to be slowly uncovered, they are far from being all unravelled.

Fortune was an exceptional writer who gave a voice to the voiceless, women and marginals. The journalist Henry W. Mitchell described her as "beyond all doubt one of the most talented, versatile and interesting writers of fiction that we have, or ever had, in the Australian colonies" $(1880,487)$. Some of her peers may have been cognizant of her identity, but they kept it secret, only at times dropping hints in their reviews, as did Henry W. Mitchell who "congratulate[d] the proprietors of The Australian Journal on their good fortune in having so gifted a writer on their staff" (487). The Melbourne magazine Table Talk also promoted the author as "probably the only truly Bohemian lady writer who has ever earned a living by her pen in Australia" $(1898,3)$, which again hints at the peculiarity of her non-conformist but self-supporting way of life. Fortune was also the first Australian writer to publish a collection of detective stories, The Detective Album: Tales of the Australian Police (1871). However, her achievement is not acknowledged in most literary analyses of the period. For instance, she is not mentioned by her contemporaries Henry Gyles Turner and Alexander Sutherland in their 1898 overview of Australian literature, otherwise a detailed nineteenth-century account of the period. Her name does not appear either in Henry Mackenzie Green's 1961 work of reference A History of Australian Literature, except for a passing allusion to her story "Dare-Devil Bob; or, the Australian Hunters" (293). But even there, Green does not acknowledge the author properly, suggesting that the story might have been the work of a better-known Australian writer, Marcus Clarke. Mary Fortune's exclusion from the more recent literary surveys may be explained by her work's specific form of publication in newspapers. Nevertheless, as this was a common feature among nineteenth-century writers, especially in Australia, where the majority of novels appeared in serial form in local papers, it is only a partial explanation. Indeed, as Katherine Bode explains, "half of all Australian novels published in these decades [1860s to 1880s] were serialised" $(2012,57)$. As some feminist studies have emphasised, the texts of colonial women writers often present "alternative 'truths"' (Bradstock and Wakeling 1991, VII) which contradict the dominant male perspective and perhaps this is a further reason for the relative lack of interest this writer has suffered from. 
Consequently, most of her texts are difficult to access nowadays. Yet, Fortune's narratives, notably her journalism, present alternate views on the construction of both the colonial Australian culture and the inclusion of women in it.

\section{Writing Australia beyond conventions of gender}

10 Fortune's retrospective tale opens on her pride in having lived an experience that was so remote from what could be expected of a lady at the time. A newspaper offered her a job as a reporter, thinking that her initials M.H.F were those of a man. But when her identity was disclosed, the newspaper withdrew their offer. Fortune includes this incident in her narrative, making fun of it, but revealing how, for a woman, being outside the norms often led to exclusion:

I was interviewed by a man who stared in open-eyed wonder at me and my youngster, whom I led by the hand.

"Are you 'M.H.F'?" he questioned with evident disbelief.

"Yes."

"I can hardly credit it. You had better see Mr. Saint; but as for the request that M.H.F would call, we want a reporter and sub-editor, and thought he might suit."

(Fortune 1882-83, 338)

In the context of the gold rush, women journalists were rare, and Fortune kept hiding her identity. Yet for the first time, in this text, her three pseudonyms and initials ("M.H.F," "W.W." and "Waif Wander") appear together, enabling the reader to make a connection between them. The articles in the series "Twenty-Six Years Ago" are signed by two pseudonyms together: "Waif Wander (W.W.)". W.W. were the initials that Fortune used to sign her detective stories, in the series "The Detective Album" that was published in The Australian Journal. The pseudonym "Waif Wander" was used for the rest of her texts, including her serial novels, short stories, articles and poems. Finally, her genuine initials, "M.H.F," standing for "Mary Helena Fortune," appear in the third serial of "Twenty-Six Years Ago," as seen in the above-mentioned quotation. Her initials "M.H.F" were never used to sign other stories. In "Twenty-Six Years Ago," the revelation of the link between the three pen names shows a certain amount of trust on the part of Fortune in the way her readership would receive her story, as well as in her own status as a woman writer that now enabled her to disclose this link. It also implies that the historical plot in "Twenty-Six Years Ago" cannot be dissociated from the autobiographical aspect of the narrative. Thus, when Fortune writes about her arrival in the colonies, she contributes to narrating the beginning of the colony itself, from the point of view of a woman travelling alone.

11 In her narrative, Fortune puts forward her unconventional way of life and always attempts to leave behind conventions of gender. When she arrives in Australia, setting foot in Melbourne, the fact that she is not accompanied is a source of astonishment for those she meets, such as the hotel manager: "I was conscious that the landlord was looking at me doubtfully, yet sympathisingly, as he told me he could put me "with the girls,' as it would hardly be safe for me to occupy a room alone" (Fortune 1882-83, 33). When she leaves Melbourne three weeks later, alone with her young son on board a stagecoach, the men she travels with are surprised to see her unchaperoned: "an' it's wonderin' I've been all the road if it's going to the diggings by yerself ye are?" (33). Despite her courage, she admits the difficulty of such a journey for a lone woman: "A woman, especially with little ones in charge, can scarcely be expected to feel safe or 
comfortable in a strange land, and among a class of people she has been told were as rough and knobby as the stones from among which they were rooting out their gold" (36). The journey through the bush had nothing of a poetic experience for the narrator: "our experience of travelling in ' 55 did not include any time to bestow on the beauties of Nature in any shape or form" (35). Material difficulties were numerous, the first of them being the cost of life in Australia.

When Fortune and her son get to Castlemain tavern, on the way to the mine called Kangaroo Flat, a woman bursts into tears, regretting even having come to Australia. This anecdote is followed by a comment from the narrator, reminding the reader that such regrets were shared by many immigrants, herself included: "What ever came over me at all to come to such an outlandish place!' she sobbed. [...] 'Ah! Many of us have come to the same conclusion many a hundred times since our voluntary expatriation" (Fortune 1882-83, 36). Expatriation, combined with estrangement from one's cultural and familial landmarks, leads to a feeling of exclusion. Similarly, in the second stagecoach that takes them to the goldfield of Kangaroo Flat, Fortune realises that her former life belongs to a past gone for good:

What fate was to be for me and mine in this land of gold over which the shadows of night were slowly dropping? [...] human nature is a strange thing, and the unknown and untried has always attractions for the sanguine and the young (36).

Despite the dangers and uncertainties, the taste for adventure can be perceived in this declaration, a feature related to her nomadic way of life.

In her memoirs, Fortune emphasises her nomadic life, as her first years were characterised by a succession of trips following the discoveries of gold deposits. This voluntary wandering calls into question the feminine domestic realm of Victorian fiction, as throughout those years, Fortune never lived in a house, and her different homes were in turn a hotel, a caravan, and a tent. In addition to the various precarious homes that she lived in, intimacy and the private sphere did not exist in the camps near the goldmines: "There were some odd scenes exposed to the public in those days, and even refined women got accustomed to perform wholly domestic duties without even a screen between them and the moving, talking, laughing, eating, or working population around them" (Fortune 1882-83, 340). The accumulation of -ING forms, juxtaposed in a (seemingly) never-ending list, echoes the number of activities practiced in the camp in public, enabling the reader to hear and read the restlessness that characterised camp life. The distinction between the private and the public spheres was not established in the camp, maybe because it was mostly a male domain, in which women were rare, thereby enabling Fortune to cross gender boundaries. Judith Brett, the great-grand daughter of Percy Brett, Fortune's second husband, considered that Fortune's main interest lay in the public sphere:

From the street, from the camping grounds she shares with the swearing drivers in "Fourteen Days on the Road" [another of Fortune's narratives of wandering] as she journeys unaccompanied in a carrier's dray, from the door of her tent as she surveys the chaotic life of the diggings, she always writes from the midst of a public space. (1989, IX)

14 On the goldfields, the absence of private space is reinforced by the fact that the narrator becomes herself a voyeur, when she observes her camp neighbours through a hole in the fabric of her tent, serving as an air vent: "From this point of observation I saw a loaded dray"; "The observation made me more closely observe the female"; "I watched the woman with interest"; "I was sitting by my ventilated slit, that I may call 
my window" (280-81). Fortune plays the role of a spectator as well as an interpreter for the reader of the colonial life on the goldfields, blurring boundaries between the public and the private, the individual and the collective, but also between literary genres.

\section{Blurring genre boundaries}

15 The narrative contains reflections by Mary Fortune on her new situation in Australia and the personal pronoun "I" is used regularly, referring to the narrator who is also the protagonist. However, the identity of the narrator is presented as plural. Her feelings, when she first awakes on the goldfields, are described as such: "To fall asleep and dream dreams that change as quickly as the forms in an unsteady kaleidoscope, and to awaken with a bewildered feeling that you are not yourself but have changed places with some other identity" (Fortune 1882-83, 280). As she wakes up in a new cultural environment, her identity landmarks are disrupted, so that the definition of identity is intimately linked to the place where the character evolves. In the colonial context, this place is linked to the notion of nation, and the different sides of identity which Fortune refers to are fragmented, separated by boundaries which are at the same time cultural, geographical and emotional: "As the twilight deepened, [...] I began to realise I was on the borders of a new life. All the perils of the sea were over, and it lay an impassable barrier between me and the old happy Canadian life" (36). The frontier is both literal and metaphorical, representing the distance between Fortune's previous place of belonging, Canada, and Australia where she has just settled. The ocean separates the two cultural sides of Fortune's identity, but the frontier is also symbolic. This moment of epiphany takes place when the sun sets, during the trip from Castlemain to Kangaroo Flat: it is therefore a moment of transition, doubly symbolised by nightfall and the trip. Yet the different aspects of the narrator's identity cannot be reunited: throughout the publication of the different narratives composing the memoirs, the pronoun "I" slowly disappears and the tone grows darker, until it becomes tragic. In the first three parts, there is an omnipresent first-person narration ("to me," "I think," "I also remember," "I remember, too," "I, myself," "I asked"), but in the last two serials, the pronoun "I" becomes more and more discreet, leaving room for elaborate descriptions of anecdotes of life on the diggings.

The anecdotes become increasingly gloomy and the number of murders keeps increasing as the narrative progresses: "A moment of throbbing and terrified suspense, and then the crushed and clay-stained body of a man was laid upon the fresh grass" (Fortune 1882-83, 381). The anecdotes that deal with life on the diggings thus start with a betrayed husband (September 1882), a bag of gold that is lost and the flooding of a tent after a storm (January 1883), a reunion between husband and wife (February 1883), before becoming even more tragic in the last two serials (March and May 1883), in which the murders are numerous. No fewer than five deaths occur, including four murders, and they are narrated in just a few pages, without any convolution this time: "As he said the words he had buried the knife deep in Lygon's breast" (508). The last of the five articles ends on the murder of a baby by his mother who becomes mad, with an abrupt conclusion: "It was a sad story, but, after the usual inquiry, poor little Possy was buried, and the wretched mother went home to her friends in town" (510).

Fortune's memoirs end on this tragic note and in this neutral tone. This conclusion is all the more surprising as the first three narratives out of the five were written with a 
more personal tone. The last two, enumerating murders, rather remind us of the detective stories that Fortune regularly wrote for The Australian Journal. Indeed, when she published "Twenty-Six Years Ago," Fortune had been writing detective stories for almost twenty years, which may explain the influence of the genre on her own memoirs, notably concerning the structure of the narrative, based on the gradual revelation of information related to a crime or a mystery, and centered on the main protagonist's quest through internal focalisation. ${ }^{2}$ With more than five hundred detective stories, Fortune was an exceptionally prolific writer in this genre, and published more than any other woman in the nineteenth century, and earlier than the American writer Anna Katherine Green, usually considered as "The Mother of Detective Fiction." ${ }^{3}$ Fortune's collection of detective stories, entitled The Detective's Album: Tales of the Australian Police (1871), was the first book of the kind to be published in Australia. Composed of seven stories taken from the series "The Detective's Album," which had initially been published in The Australian Journal in 1870 and 1871, it was unfortunately not republished and one single copy has survived to this day. ${ }^{4}$ The series "The Detective's Album" started in 1868 and went on until 1908, with an average of twelve short stories a year. The tales are narrated in the first person by Detective Mark Sinclair, an innovative narrative strategy at the time. The voice of Sinclair is quite close to that used by Fortune in her journalism, for instance addressing the reader in a familiar way. As Lucy Sussex has underlined in "A Woman of Mystery," Fortune's journalism and her detective stories are often similar.

Fortune, while being an outsider to the male world of police, had enough knowledge on this issue to write plausible detective stories. Her second husband, Percy Brett, whom she met on the diggings, was a member of the mounted police, and her experience on the goldfields had enabled her to become familiar with an often dangerous environment, herself having been the witness of a murder. Thus, her autobiographical narrative "Twenty-Six Years Ago," in between the genres of journalism and detective stories, testifies to her experience as a writer of detective stories and the reality of the violent life on the diggings. As the historian Charles M. Clark recalls, "[the mining towns] were frontier situations where frequently the normal civilized standards were forgotten. In many of the digging sites it was a journey back into primal behaviour with barbarism on the march" $(1960,133)$.

The papers of the time also report the high rate of criminality on the diggings, as The Maryborough and Dunolly Advertiser, which was circulated on the goldfields of Avoca in Victoria, where Fortune lived for some time. Crimes and offences were commonplace, including theft, smuggling, murder, sexual abuse, deadly accidents, as well as suicides. Fortune drew inspiration from these incidents for her journalism as well as her detective stories. But if her journalism is inspired by detective stories, the detective tales can also be considered as a written trace of the colonial experience. For example, the series "Adventures of a Mounted Trooper," which Fortune regularly contributed to, was explicitly promoted by The Australian Journal as the narration of extraordinary events that were part of the history of the colonies: "These narratives will be of the most spirited description, and embrace the most extraordinary adventures and perils that have characterised the history of the colonies" ("Notices" 1865, 156). Detective stories and crimes are presented here as being part of the colonial Australian identity and Fortune's narratives, published in newspapers, can be seen as examples of a blurring of genres. 
In “Twenty-Six Years Ago: or, the Diggings from '55," Mary Fortune provides an autobiographical account of an unconventional woman's life on the Australian goldfields. Fallen into oblivion in the course of the twentieth century, like the rest of Fortune's production, this narrative however expresses a woman writer's desire for independence as well as a refusal to conform to a conventional, "womanly" way of life. Fortune is thus characterised by various forms of exception, both on the historical and literary levels: her exclusion from the Australian literary histories despite having been one of the most prolific and popular writers in nineteenth-century Australia; her eccentric and marginal way of life; and her exceptional texts showing a desire to write beyond norms of genre or gender. "Twenty-Six Years Ago" is indeed situated at the crossroads between autobiography, journalism and fiction, notably detective fiction. Yet the last episode from the series, the most tragic one, also marks the end of Fortune's autobiographical narratives and journalism, in May 1883. From this date onwards, she would never write journalism again and would carefully remain hidden behind her pseudonym, refusing to unveil her identity in her tales and writing fiction that could easily make good copy in order to earn a living, only living her marginal life out of sight. However, she left a huge body of work, most of it still waiting to be rediscovered and read.

\section{BIBLIOGRAPHY}

ADELAIDE, Debra, ed. 1988. A Bright and Fiery Troop: Australian Women Writers of the Nineteenth Century. Ringwood, Vic.: Penguin.

BODE, Katherine. 2012. Reading by Numbers: Recalibrating the Literary Field. London: Anthem Press. BRADSTOCK, Margaret, and Louise Katherine WAKELING. 1991. Rattling the Orthodoxies: A Life of Ada Cambridge. Ringwood, Vic.: Penguin (assisted by the Literature Board of the Australia Council). BRETT, Judith. 1989. "Preface.” In The Fortunes of Mary Fortune, edited by Lucy Sussex, IX-XI. Ringwood, Vic.: Penguin.

CLACY, Ellen ("Mrs. Charles Clacy"). 1853. A Lady's Visit to the Gold Diggings of Australia in 1852-53. London: Hurst \& Blackett.

CLARK, Charles M. 1978. A History of Australia, Vol. 4: The Earth Abideth Forever. 1851-1888. Melbourne: Melbourne University Press.

DAVISON, Graeme. 2011. “Gold-Rush Melbourne.” In Gold: Forgotten Histories and Lost Objects of Australia, edited by Iain McCalman, Alexander Cook and Andrew Reeves, 52-66. Cambridge: Cambridge University Press.

QUEEN, Ellery (Manfred Bennington LEE and Frederic DANNAY). 1951. Queen's Quorum: A History of the Detective-crime Short Story as Revealed in the 106 Most Important Books Published in this Field Since 1845. Boston: Little, Brown. 
ERSKINE, John Elphinstone. 1851. A Short Account of the Late Discoveries of Gold in Australia: With Notes of a Visit to the Gold District. London: T. \& W. Boone.

FORTUNE, Mary (“Waif Wander"). 1868. "Fourteen Days on the Road.” The Australian Journal 4, no. 170 (28 November): 217-21.

FORTUNE, Mary (“W.W.”). 1871. The Detective's Album: Tales of the Australian Police. Melbourne: Clarson, Massina, \& Co.

FORTUNE, Mary (“Waif Wander"). 1882-83. “Twenty-Six Years Ago: or, the Diggings from '55." The Australian Journal (September 1882, January-May 1883): 33-37, 280-85, 338-43, 370-84, 445-48, 508-10.

GELDER, Ken, and Rachael WEAVER. 2010. The Anthology of Colonial Australian Romance Fiction. Carlton, Vic.: Melbourne University Press.

GREEN, Anna Katherine. 2010. The Leavenworth Case. 1878. London: Penguin.

GREEN, Henry Mackenzie. 1968. A History of Australian Literature, Pure and Applied. 1961. Sydney: Angus and Robertson.

HоwITT, William. 2010. Land, Labour, and Gold. Two Years in Victoria: with Visits to Sydney and Van Diemen's Land. 1855. Cambridge: Cambridge University Press.

HUME, Fergus. 2017. The Mystery of a Hansom Cab. 1886. Mineola: Dover Publications.

LANG, John. 1855. The Forger's Wife. London: Ward and Lock.

MITCHELL, Henry W. 1880. “A Well Known Contributor: Waif Wander.” The Australian Journal 15 (March).

MORRISON, Elizabeth. 1995. "Serial Fiction in Australian Colonial Newspapers." In Literature in the Market Place: Nineteenth-Century British Publishing and Reading Practices, edited by John O. Jordan and Robert L. Patten, 306-24. Cambridge: Cambridge University Press.

“Notices." 1865. The Australian Journal 1, no. 10 (4 November): 156.

SHERIDAN, Susan. 1995. Along the Faultlines: Sex, Race and Nation in Australian Women's Writing, 1880s-1930s. St Leonard, NSW: Allen \& Unwin.

SPENDER, Dale, ed. 1988. Writing a New World: Two Centuries of Australian Women Writers. London: Pandora.

SUSSEX, Lucy. 1988. “'Shrouded in Mystery': Waif Wander (Mary Fortune).” In Adelaide 117-31.

SUSSEX, Lucy. 2005. "Cherchez les femmes: The Lives and Literary Contribution of the First Women to Write Crime Fiction." Doctoral thesis, Cardiff University.

SUSSEX, Lucy. 2009. “A Woman of Mystery: Mary Fortune.” The Lucy Sussex Home Page. 5 February. http://www.sussex.id.au/home/index.php/1800austwomencrimefiction/womanofmystery. SUSSEX, Lucy. 2016. “Writing Mary Fortune's Marginal Life.” Presentation at the Australian Historical Association conference. Ballarat, Vic., Australia. 4-8 July.

Table Talk. 1898. Melbourne, Vic. 25 March: 3.

TURNER, Henry Gyles, and Alexander SUTHERLAND. 1898. The Development of Australian Literature. London: Longmans, Green. 


\section{NOTES}

1. Ellen Clacy's narrative was published under the name of "Mrs. Charles Clacy," stating her matrimonial status on the cover page, as was regularly the case for many women at the time.

2. For more information on women's crime fiction, see Sussex 2005.

3. The detective genre has particularly been associated with Conan Doyle's Sherlock Holmes, but several earlier examples can be found, such as Inspector Bucket in Charles Dickens' Bleak House (1852-53), but also John Lang's The Forger's Wife (1855), Fergus Hume's The Mystery of Hansom Cab (1886), two of the early Australian detective stories. Anna Katherine Green obtained international recognition after her novel The Leavenworth Case (1878). According to Ellery Queen (the collective pseudonym of the two American writers Manfred Bennington Lee and Frederic Dannay), Green was the first woman to write detective stories: "[she was] the first woman to write 'pure' detective stories in any land or language" (Queen 1951, 64).

4. The collection contains the following tales: "The Evidence of the Grave," "The Hart Murder;" "The Last Scene," "The Twenty-Ninth of November," "To Be Left Till Called For," "A Woman's Revenge: or, Almost Lost," "The Diamond Robbery."

\section{ABSTRACTS}

In "Twenty-Six Years Ago: or, the Diggings from '55," published in The Australian Journal (1882-83), Waif Wander (Mary Fortune's pen name) provides an autobiographical account of an unconventional woman's life on the Australian goldfields. This article seeks to stress the unconventionality of Mary Fortune's memoirs, written beyond norms of genre and gender, in order to contribute to their re-evaluation. It addresses Fortune's exclusion from the Australian literary histories as well as her eccentric and marginal way of life.

INDEX

Keywords: Mary Fortune, Waif Wander, memoirs, colonial Australia, exclusion, exception

\section{AUTHOR}

\section{ALICE MICHEL}

Université d'Orléans

Alice Michel completed her thesis in 2017 and holds a teaching position as professeur agrégé at the University of Orléans. Her main research interests are neglected women's journalism and serial fiction, Australian literature and culture, and the sociology of literature. Her articles include "Hidden Fortunes of Colonial Australian Popular Fiction: Women in Mary Fortune's 'Dora Carleton'," published in The Journal of the European Association for Studies of Australia (2016). 